\title{
Women's career and teachers in-service training in primary education in Greece. Social determination and personal choices
}

\author{
Dimitris K. Vergidis, Anastasios Tzintzidis \\ University of Patras, Department of Education, \\ Rion-Patras, 26500, Greece \\ University of Patras, Department of Education, \\ Rion-Patras, 26500, Greece
}

\begin{abstract}
The article examines how the gender is central to an understanding women teachers' occupational route and is focused on module choice processes modules at the In-Service Teacher Training Unit (Didaskaleio) department of General Pedagogy in the University of Patras. We examine the modules which women teachers at In-Service Teacher Training Unit of Patras chose to attend, in order to explore their interest and their professional perspectives. From the study and the program of the In-Service Teacher Training Unit of Patras of the academic years 1998-2002 we found the modules offered by the School. Then we codified the titles of the modules in order to facilitate their statistical process and we checked which modules had been taught. Next, we examined the personal portfolios of teachers per each year of attendance and we collected data with reference to the choices of their modules.
\end{abstract}

\section{Indexing terms/Keywords}

In-service teachers training; gender equality; Greece; greek primary education; women teachers' occupational route.

\section{Academic Discipline And Sub-Disciplines}

Science Education

\section{Council for Innovative Research}

Peer Review Research Publishing System

Journal of Social Science Research

\author{
Vol.1 No.1 \\ editor@ijssronline.com \\ www.cirworld.com, www.ijssronline.com
}


In the selection of the Heads of Regional Educational Offices, in Greece, very little participation of women was observed (once again). The number of women selected for these positions was extremely small. The number of women candidates was also quite limited.

Is it a matter of women's personal choices or reproduction of their role and social determination? This is not only a question of research but also one of social and political interest.

In this article we shall refer to data that shows that in Greek primary education a female occupational route has been formed, not routed through managerial positions, which male colleagues assert and take up. More specifically, we shall examine women teachers' choices of modules at the In-Service Teacher Training Unit (Didaskaleio) Department of General Pedagogy in the University of Patras (Greece), and we shall show that women teachers choose modules that fall into a female occupational route. We shall specifically show that the choice of modules by teachers studying at the Teacher Training Unit is gender defined.

\section{The female occupational route: difference or/and inequality?}

While women in Greece are orientated more than men towards pedagogic studies (Antoniou, 2002) and the percentage of female primary school teachers is $56,8 \%$, the number of women in managerial positions in Greek education (Heads of schools, School Advisors, Heads of Regional Education Offices) are very small.

The percentages of women in the fields of Pedagogy, Sociology and Psychology (period 1979-1991) who graduated from universities abroad, according to data by DIKATSA (Inter-University Center for the Recognition of Foreign Academic Titles) are the following:

- In education: $67,1 \%$ of the total received postgraduate degrees, $49 \%$ a Ph.D.

- In sociology: women with a post-graduate degree $58,8 \%$ of the total, and with a doctorate of candidate $43,9 \%$.

- In psychology: women with a post-graduate degree $79,8 \%$ of the total, and with a doctorate of candidate $56,5 \%$ (Patiniotis, 1996).

In primary education, women constitute the majority of teachers who are highly qualified though very few (precious few) of them assert and take up managerial positions. This official inequality indicates a dissimilar development in their personal career in comparison with those of their male colleagues. Regarding the question of why so few women take up managerial positions in education, we could hypothesise that there is unequal treatment by boards that select or that women teachers choose themselves not to pursue a career in this direction. Thus, we would cancel the question, oversimplifying the social dimensions of this phenomenon.

Two main theoretical approaches have been put forward as possible explanations of this phenomenon:

a) The theory which focuses on the role of gender, according to which there are intrinsic differences between men and women, which account for the unequal number of men and women in managerial positions (Kergoat, 2008, p. 132).

b) The theory of social role, which argues that the socialization of women may lead them to believe that they have fewer opportunities for advancement in managerial positions than men. This means that males and females have different beliefs, attitudes and values that influence their desires for advancement (Chadwick, 1989). Females tend to accept a job rather than to pursue a career (Wood \& Lindorff, 2001; Frosi, 2010, p. 21).

Females seem to be less interested than males in their advancement to higher positions during their career (Morgan, 1989). This can be explained by the differences in the way in which they choose and rate the kinds of their obligations and duties. Perhaps females like to use their time and energy in other ways.

A key issue in the area of employment equality is whether the ultimate aim should be equality of opportunity for women and men or equal gender representation in all occupations and at all levels (O' Connor, 2001).

Studies of teachers' careers [Inner London Education Authority (1984; 1987); Grant (1986); Kant (1985)] have shown some of the ways in which promotion and development are not "working properly" (Al-Khalifa, 1989).

With reference to relevant research in this area in Greece, Saiti (2000), in her survey, mentions a female teacher's tension which was due to her reluctance to take up a managerial position.

More specifically, Saiti found that:

- The female teacher respondent's interest in managerial positions is relatively low due to family burdens. However, both single and married female teachers without children who have less family burdens are more reluctant to take up managerial positions.

- The single and "new in-service" female teachers appear to avoid even more assuming managerial responsibilities in school than married female teachers.

- $\quad$ The single female teachers show more disinclination for managerial promotion in comparison with married ones. 
- A considerable percentage of respondents $(37,4 \%)$ considers managerial positions in educational hierarchy to be a male privilege.

Athanassoula-Reppa et.al. (Athanassoula-Reppa, 1999; Athanassoula-Reppa, \& Koutouzis, M. 2002) researched the reasons for women's under-representation in decision making in public education and especially in educational managerial positions and she detected the perspective of counterbalance in their participation. They also describe the inequality and women's under-representation in the staffing of management positions of educational institutions and reffers to relevant surveys on women's low participation in taking up managerial positions in education. According to these surveys, women are less to assert managerial positions in education because they fear a conflict of roles. Furthermore, the programs for professional development don't help women. As Robertson emphasizes "The sentiment against the subject of gender demands the recognition and incorporation of knowledge about their differences between men and women in conception, in planning and implementation of professional development programs" (Robertson, 1995, p. 77). Thus, women fearing the additional burden of responsibilities and the conflict of roles give priority to their teaching career in the classroom and not to managerial positions. Women that follow the teaching profession want to be teachers and not headmistresses. It seems that there is a gender hierarchy (Nickel, 2010, p. 288).

Vasilou-Papageorgiou (1995) maintains that the choice of profession for women as well as their low participation in managerial positions is not interpreted only in terms of aptitude and psychological motivation but is connected to multiple historical, social-political, ideological and cultural factors. She argues that there are barriers in women's professional advancement that are innate in the educational institution itself and bring about their self-exclusion from managerial positions. There are difference among opportunities, circumstances, and systems of selection and organization of educational institutions. Therefore, self-exclusion is translated as the adoption or repression of women's ambitions and expectations. A woman in order to achieve managerial positions in education needs to adopt male patterns and ways of management.

Robertson (1995) argues that females avoid managerial positions because this role usually coincides with arbitrariness and the hard productivity orientated way of management.

Two more reasons that have been suggested for the female absence from managerial positions in education are on the one hand, that women lose heart because of the preparation that is required for these positions and that the boards do not select them on the other (Glass, 2000).

Women also take up managerial positions later than their male peers. As lordanidis (2002), notes: "... the percentage of female participation at middle level as Heads of Regional Education Offices is really surprisingly low, despite the legislation of recent decades that promotes equality between the sexes. It could be assumed that women's low participation in these managerial positions relates to the process of selection. Men and women who are interested in the positions of Heads of Regional Education Offices are selected according to applied criteria of selection.

It seems that the male over-representation in the position of Head of Regional Education Offices is a result of women's personal choices not to assert the position, as they fail to apply, apparently due to their family responsibilities" (Iordanidis, 2002, p. 115).

In Table 1 we set out data for the selection of Heads of Regional Education Offices and School advisors (Primary Education) during the last decade 1993-2002 and the gender distribution of this selection. According to the recent selections of 2002, there are only 12 women at the position of Heads of Regional Education Offices. 
Table 1. Selection of heads of Regional Education Offices and School advisors (Primary Education)

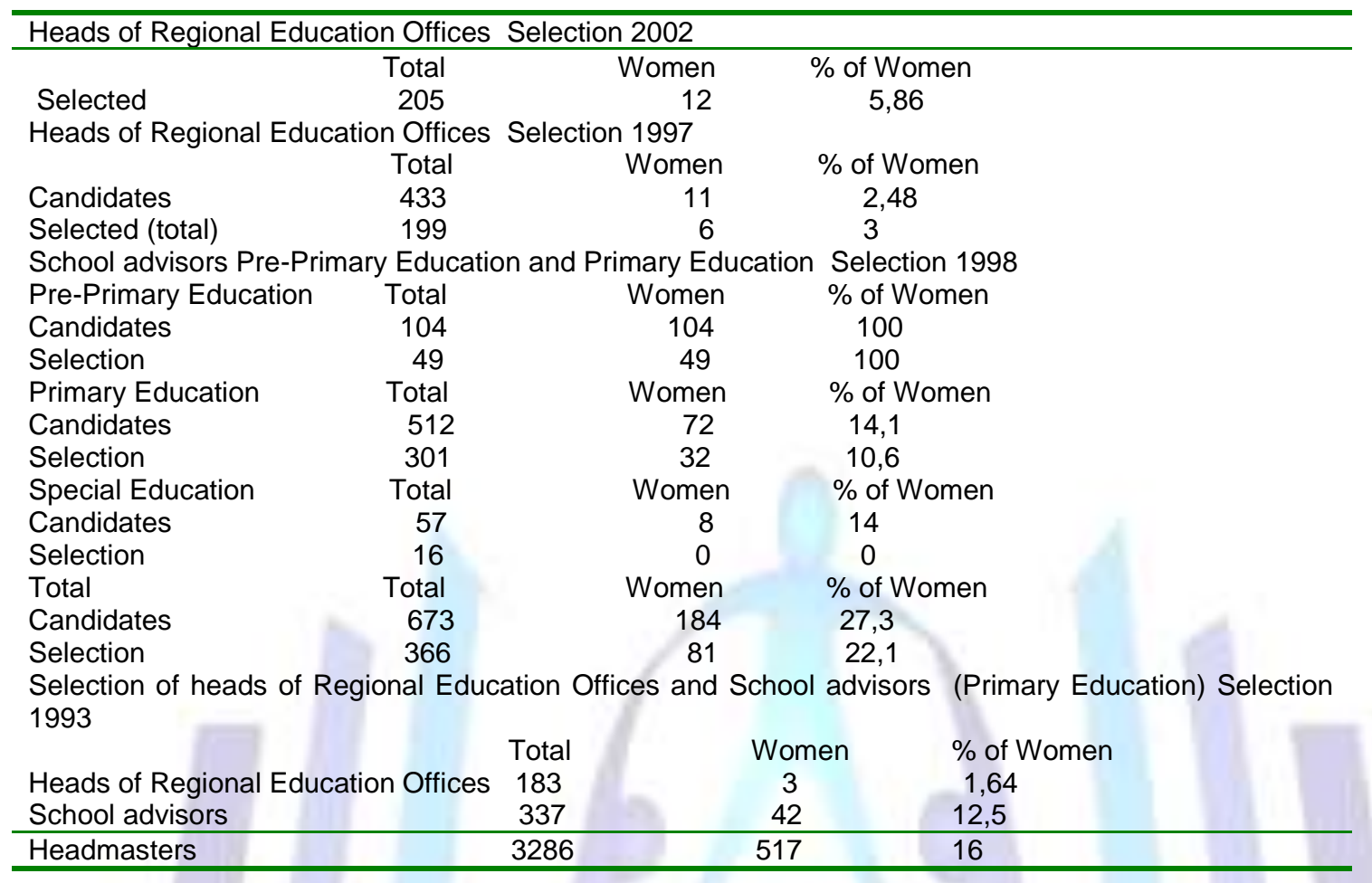

From the data in Table 1 we can see the over-representation of men in managerial positions and women's underrepresentation. Even if women manage to break the glass ceiling and reach managerial positions, they will confront an established situation which is hardly reversible. We must point out that in the long run the number of women who assert and take up managerial positions has increased, but their proportion remains very small.

\section{Women participation in In-Service Teacher Training Units}

The law of $2327 / 95$ integrated the Teacher In-Service Training Units (Didaskaleia) into the Primary Education Departments of the Universities, which have the responsibility for their organization and function. The selection of applicants is through written examinations. Teachers of public and private primary education that have teaching experience from a minimum of 5 to a maximum of 25 years can participate in the process of selection. Attendance at the In-Service Teacher Training Units (Didaskaleia) lasts for four semesters. It is obligatory and during this period of time teachers are excused from their teaching and managerial tasks.

Teachers who graduate from In-Service Teacher Training Units (Didaskaleia) acquire a degree in education.

On the whole, six In-Service Teacher Training Units integrated into the Primary Education Departments of the Universities (Athens, Thessaloniki, loannina, Patras, Rethymno and Rhodes) have gradually started functioning since 1995. Thus, there has been a significant increase in the number of teachers studying at In-Service Teacher Training Units across the country. Therefore the teachers who could not in Athens had access to Training Units in other cities of the country.

Table 2 sets out the gender distribution of teachers who entered the In-Service Teacher Training Units during the years 2000, 2001, and 2002. 
Table 2. Number of teachers at In-Service Teacher Training Units (2000-2002)

\begin{tabular}{|c|c|c|c|c|c|c|c|c|c|}
\hline \multicolumn{10}{|c|}{ In-Service Teacher Training Units } \\
\hline & \multicolumn{3}{|c|}{2000} & \multicolumn{3}{|c|}{2001} & \multicolumn{3}{|c|}{2002} \\
\hline & $\mathrm{T}$ & W & $\mathrm{W}(\%)$ & $\mathrm{T}$ & W & $\mathrm{W}(\%)$ & $\mathrm{T}$ & W & $\mathrm{W}(\%)$ \\
\hline Athens & 86 & 55 & 64 & 91 & 66 & 72,5 & 87 & 56 & 64,4 \\
\hline Thessaloniki & 68 & 40 & 58,8 & 73 & 53 & 72,6 & 74 & 43 & 58,1 \\
\hline Patras & 48 & 19 & 39,6 & 49 & 25 & 51 & 46 & 24 & 52,2 \\
\hline Ioannina & 37 & 20 & 54,1 & 34 & 18 & 52,9 & 41 & 20 & 48,8 \\
\hline Rethymno & 43 & 23 & 53,5 & 45 & 25 & 55,6 & 40 & 24 & 60 \\
\hline Rhodes & & & & 32 & 16 & 50 & 34 & 16 & 47,1 \\
\hline Total & 282 & 157 & 55,7 & 324 & 203 & 62,7 & 322 & 183 & 56,8 \\
\hline (T:Total & $\mathrm{W}: \mathrm{W}$ & & $\mathrm{W}(\%$ & f Wor & & & & & \\
\hline
\end{tabular}

As we can see, over the last few years the majority of teachers admitted to In-Service Teacher Training Units have been female. We must add that the Presidential Decree 25/2002 defines the selection criteria for the selection process of School Advisors and Heads of Regional Education Offices.

Specifically according to this Presidential Decree the selection criteria are:

1. Article 10. Criteria Selection of School Advisors. "...All academic or other qualifications which can be proven by relevant degrees, certificates etc. For example: a) doctorate degree merits 8 units, b) post-graduate degree merits 4 units, c) In-Service Teacher Training Unit degree merits 4 units..."

2. Article 14. Criteria Selection of Heads of Regional Education Offices. "...All academic or other qualifications which can be proven by relevant degrees, certificates etc. For example: a) doctorate degree merits 8 units, b) post-graduate degree merits 4 units, c) In-Service Teacher Training Unit degree merits 4 units..."

As we see, the degree offered by the In-Service Teacher Training Unit, as a selection criterion of School Advisors and Heads of Regional Education Offices merits 4 units.

We have found that women teachers studying at In-Service Teacher Training Unit are not orientated towards modules related to School Management, but towards subjects which are more related to teaching in class and in particular to cultural education, as these choices seem to conform to relative professional interests.

We note that becoming a Headmaster in Primary Education constitutes an important step in a teacher's career towards advancement in higher managerial positions. However, women in general do not take up positions that normally bring them to managerial positions of education (Glass 2000). Indeed, at the In-Service Teacher Training Unit of Patras most of the teachers who have worked as Headmasters at schools before their training are male.

At this point, we shall examine the modules which women teachers at In-Service Teacher Training Unit of Patras chose to attend, in order to explore their interest and their professional perspectives. From the study and the program of the InService Teacher Training Unit of Patras of the academic years 1998-2002 we found the modules offered by the School. Then we codified the titles of the modules in order to facilitate their statistical process and we checked which modules had been taught. Next, we examined the personal portfolios of teachers per each year of attendance and we collected data with reference to the choices of their modules.

The data that we selected was codified and processed using the Statistical Package Research for Social Sciences (SPSS). The correlations we found were consistent with our hypothesis. The gender was considered as an independent variable according to our hypothesis. The modules and the study areas which teachers at In-Service Teacher Training Unit of Patras have chosen were considered as dependent variables. The correlations are interpreted at level $99 \%(p<0,01)$ as statistically important.

In the next section we shall refer to the targets of In-Service Teacher Training Unit of Patras as well as to its program.

\section{Aims of the In-Service Teacher Training Unit of Patras}

According to the Study Guide of the In-Service Teacher Training Unit of Patras, the teachers must "go into a scientific area acquiring an informal specialization - (for example in management of education, social exclusion etc.)". It is also stressed that "the ultimate aim of In-Service Teacher Training Unit is that teachers should return to education having acquired new, contemporary scientific knowledge and, if possible, having formed new attitudes, which shall enable them to improve not only their everyday teaching and educational function, but also to take up executive posts in education, thus contributing to the whole improvement of education".

As we can see, the In-Service Teacher Training Unit has two basic complementary but distinct aims; on the one hand, the improvement of everyday teaching and educational function of graduates, and on the other hand, the filling of vacant executive posts in education.

We must add that at the In-Service Teacher Training Unit of Patras the following four study areas of modules are offered: (It should be noted that the fourth study area has not run). 
1. The teaching of language.

2. Social and educational exclusion, intercultural education.

3. Management and planning of education.

4. The teaching of Physics and Mathematics.

Prerequisite for the implementation of a study area is the participation of at least 15 teachers. Teachers have the possibility of options in most of the modules. In order to obtain the degree of the In-Service Teacher Training Unit, the teachers must have taken 24 modules from a total of 65 included in the guide and passed the examinations. More specifically :

a) 5 set subject / text modules.

b) 5 modules from the study area which they have chosen.

c) 14 modules from any study area which they wish.

From the processing of the choices of study areas of teachers for the years 1998-2002 we came up with the following: (see Table 3).

Table 3. Choices of study areas of teachers at the In-Service Teacher Training Unit of Patras (1998/99 -2001/2002)

\begin{tabular}{lcccc}
\hline study areas & total & women & women\% & \%within women \\
\hline $1^{\text {st }}$ & 44 & 26 & 59,1 & 37,68 \\
$2^{\text {nd }}$ & 40 & 24 & 60,0 & 34,78 \\
$3^{\text {rd }}$ & 61 & 19 & 31,1 & 27,53 \\
\hline total & 145 & 69 & 47,58 & 100 \\
\hline
\end{tabular}

The statistic $x^{2}$ has a rate of 11,415 and $p=0,003<0,05$ and shows that statistically there is a very important correlation between the gender of teachers and the study area which they choose. Men choose the $3^{\text {rd }}$ study area «Management and Planning of Education» while women the $1^{\text {st }}$ and $2^{\text {nd }}$, that is to say "The Teaching of Language» and «Social and Educational exclusion. Intercultural education». 
In Table 4, we present the choices of modules for the 3 periods $1998-2000,1999-2001,2000-2002$.

Table 4. Choices of modules of teachers at the In-Service Teacher Training Unit of Patras (1998/99 -2001/2002)

\begin{tabular}{|c|c|c|c|c|c|c|c|}
\hline \multirow[t]{3}{*}{$\mathrm{N} / \mathrm{N}$} & \multirow[t]{3}{*}{ Module } & \multicolumn{6}{|c|}{ Total choices of modules } \\
\hline & & $\begin{array}{l}\text { Tot } \\
\text { al }\end{array}$ & Women & $\begin{array}{l}\text { Women } \\
\%\end{array}$ & $\begin{array}{l}\% \\
\text { within }\end{array}$ & $\begin{array}{l}\text { Place at } \\
\text { the }\end{array}$ & $\begin{array}{l}\text { Place at } \\
\text { the }\end{array}$ \\
\hline & & & & & Women & $\begin{array}{l}\text { men's } \\
\text { choices }\end{array}$ & $\begin{array}{l}\text { women's } \\
\text { choices }\end{array}$ \\
\hline 1 & $\begin{array}{l}\text { Organization } \\
\text { management with } \mathrm{P} / \mathrm{C}\end{array}$ & 113 & 53 & 46,9 & 75,7 & $1^{\text {st }}$ & $4^{\text {th }}$ \\
\hline 2 & $\begin{array}{l}\text { Theory and practice of art of the } \\
\text { theatre }\end{array}$ & 113 & 59 & 52,2 & 84,3 & $4^{\text {th }}$ & $1^{\text {st }}$ \\
\hline 3 & $\begin{array}{l}\text { The place of experiments in the } \\
\text { teaching of physics }\end{array}$ & 103 & 45 & 43,7 & 64,3 & $2^{\text {nd }}$ & $7^{\text {th }}$ \\
\hline 4 & Teaching of culture & 101 & 50 & 49,5 & 71,4 & $5^{\text {th }}$ & $5^{\text {th }}$ \\
\hline 5 & $\begin{array}{l}\text { Analytical programs and } \\
\text { linguistic cultural minorities }\end{array}$ & 97 & 54 & 55,7 & 77,1 & $11^{\text {th }}$ & $3^{\text {rd }}$ \\
\hline 6 & $\begin{array}{l}\text { Modern-greek literature. its } \\
\text { teaching }\end{array}$ & 93 & 47 & 50,5 & 67,1 & $8^{\text {th }}$ & $6^{\text {th }}$ \\
\hline 7 & $\begin{array}{l}\text { Theatre and linguistic } \\
\text { development }\end{array}$ & 92 & 55 & 59,8 & 78,6 & $14^{\text {th }}$ & $2^{\text {nd }}$ \\
\hline 8 & $\begin{array}{l}\text { Educational use of } \mathrm{P} / \mathrm{C}- \\
\text { educational software }\end{array}$ & 89 & 39 & 43,8 & 55,7 & $6^{\text {th }}$ & $9^{\text {th }}$ \\
\hline 9 & $\begin{array}{l}\text { Organization-management of } \\
\text { school units }\end{array}$ & 89 & 34 & 38,2 & 48,6 & $3^{\text {rd }}$ & $15^{\text {th }}$ \\
\hline 10 & $\begin{array}{l}\text { Teaching of special modules: } \\
\text { religion }\end{array}$ & 85 & 39 & 45,9 & 55,7 & $9^{\text {th }}$ & $10^{\text {th }}$ \\
\hline 11 & Organizational psychology I & 82 & 36 & 43,9 & 51,4 & $7^{\text {th }}$ & $13^{\text {rd }}$ \\
\hline 12 & Intercultural education & 80 & 39 & 48,8 & 55,7 & $12^{\text {th }}$ & $11^{\text {th }}$ \\
\hline 13 & Family sociology & 79 & 42 & 53,2 & 60 & $15^{\text {th }}$ & $8^{\text {th }}$ \\
\hline 14 & $\begin{array}{l}\text { Multimedia. } \\
\text { approaches with use of } \\
\text { educational software }\end{array}$ & 72 & 31 & 43,1 & 44,3 & $13^{\text {th }}$ & $16^{\text {th }}$ \\
\hline 15 & $\begin{array}{l}\text { Managing education theory } \\
\text { and practice }\end{array}$ & 71 & 26 & 36,6 & 37,1 & $10^{\text {th }}$ & $17^{\text {th }}$ \\
\hline 16 & $\begin{array}{l}\text { Communicational method in } \\
\text { teaching the language }\end{array}$ & 68 & 38 & 55,9 & 54,3 & $18^{\text {th }}$ & $12^{\text {th }}$ \\
\hline 17 & Young children's literature & 65 & 34 & 52,3 & 48,6 & $17^{\mathrm{th}}$ & $14^{\text {th }}$ \\
\hline 18 & $\begin{array}{l}\text { Methodology I }- \text { applied } \\
\text { statistics }\end{array}$ & 53 & 21 & 39,6 & 30 & $16^{\text {th }}$ & $20^{\text {th }}$ \\
\hline 19 & $\begin{array}{l}\text { Educational policy and social } \\
\text { exclusion }\end{array}$ & 50 & 22 & 44 & 31,4 & $20^{\text {th }}$ & $19^{\text {th }}$ \\
\hline 20 & $\begin{array}{l}\text { Modern tendencies of } \\
\text { philosophy }\end{array}$ & 48 & 19 & 39,6 & 27,1 & $19^{\text {th }}$ & $21^{\text {st }}$ \\
\hline 21 & $\begin{array}{l}\text { Modern greek history - teaching } \\
\text { methodology }\end{array}$ & 42 & 18 & 42,9 & 25,7 & $21^{\mathrm{st}}$ & $22^{\text {nd }}$ \\
\hline 22 & Curricula of language & 33 & 23 & 69,7 & 32,9 & $23^{r d}$ & $18^{\text {th }}$ \\
\hline 23 & Teaching the language & 28 & 17 & 60,7 & 24,3 & $22^{\text {nd }}$ & $23^{\text {rd }}$ \\
\hline
\end{tabular}

Modules of the $3^{\text {rd }}$ study area (Organization - management and planning of education) appear in bold face

As we noted above, the most significant differentiations with regard to the choice of modules according to the gender are the following:

i. The module "Management of school units" ranks in the $3^{\text {rd }}$ place of men's choices and in the $15^{\text {th }}$ place of women's choices $(p=0,003)$.

ii. The module "Organizational Psychology I" ranks in the 7th place of men's choices and in the $13^{\text {th }}$ place of women's choices.

iii. The module "Managing education theory and practice" ranks in the $10^{\text {th }}$ place of men's choices and in the $17^{\text {th }}$ place of women's choices $(p=0,008)$.

iv. The module "Theatre and linguistic development" ranks in the $2^{\text {nd }}$ place of women's choices and in the $14^{\text {th }}$ place of men's choices $(p=0,000)$. 
v. The module "Analytical Programs and linguistic cultural minorities" ranks in the $3^{\text {rd }}$ place of women's choices and in the $11^{\text {th }}$ place of men's choices $(p=0,009)$.

vi. The module "Family sociology" ranks in the $8^{\text {th }}$ place of women's choices and the $15^{\text {th }}$ place of men's choices $(p=0,003)$.

vii. Also, the module "Theory and practice of theater art" ranks in the $1^{\text {st }}$ place of women's choices and in the $4^{\text {th }}$ place of men's choices.

Statistical analysis shows that there is a statistically important correlation between the gender of trainees and the choices of their modules.

Specifically, men more than women choose to do the modules that are related to the management of school units, education theory and practice, as well as Organizational Psychology.

Women choose modules which are related to language and literature (Theatre and linguistic development, communicational method in teaching the language, syllabus design and linguistic and cultural minorities).

\section{CONCLUSIONS}

It is clear that over the years women teachers have been under-represented in managerial positions of Primary Education. Research has shown that women show reluctance to take up managerial positions not only because of their heavy family burdens in comparison to their male colleagues, but also for reasons related to their perceptions and their expectations (Al-Khalifa, 1989). Managerial positions appear to be considered as men's privilege.

Despite all this, the limited number of candidates for managerial positions is in sharp contrast to definite women's trend to acquire high educational credentials, both at master-degree level and studying at In-Service Teacher Training Unit.

Female teachers tend to participate and succeed in passing the exams for the In-Service Teacher Training Unit, retaining their traditional view that managerial positions in education are a "male privilege". As we noted, women comprise a large percentage of successful candidates for the exams of In-Service Teacher Training Unit.

In the case of In-Service Teacher Training Unit under study, female teachers are almost $50 \%$ of the whole, but very few of them choose the study area that relates to Management and planning of education, with a view to asserting a managerial position. On the contrary, they prefer to attend classes of art and culture and classroom teaching. With regard to the question of whether it is a matter of social reproduction of their role or personal choice strategies, we cannot answer with certainty within the framework of this work. We can assert though that women teachers have acquired substantial educational credentials in comparison to their males colleagues and they have created the prerequisites to assert their professional promotion to managerial positions. However, as we found out, from the two categorical aims of In-Service Teacher Training Unit, female teachers mainly pursue the improvement of their everyday educational task, while their male colleagues pursue executive positions.

These two distinct professional routes are possibly rooted and reproduced by the criteria of choice of managerial and executive positions, and the significance of the different selection criteria (De Lyon \& Widdowson - Migniulo, 1989). Indeed careful examination of the criteria of the category of "Scientific and educational proficiency and concurrence", are counterbalanced by the criteria of the categories "Official situation and teaching experience" and "Practice of directional work and managerial tasks".

It is very probable that the criteria of choice contribute to the consolidation and reproduction of entering a professional teaching career, which is connected to gender. The question of how the various criteria function in connection with gender remains to be answered.

\section{REFERENCES}

[1] Al-Khalifa, E. (1989) Management by halves: Women teachers and school management, in De Lyon, H. \& Widdowson - Migniulo, F. (Eds) Women teachers. Issues \& experiences (Milton Keynes, Open University Press, 8396).

[2] Antoniou, C. (2002) The education of Greek Teachers (1828-2000) (Athens, Ellinika Grammata Publish, in Greek).

[3] Athanasoula - Reppa, A. (1999) Women's under-representation in the centers of decisions of education. An aspect of unequal distribution of power in school mechanisms, paper presented at 7th Scientific Conference Saki Karagiorga, April 21-24, Panteios University, (in Greek).

[4] Athanassoula-Reppa, A. \& Koutouzis, M. (2002) Women in Managerial Positions in Greek Education: Evidence of Inequality, Web Edition Education Policy Analysis Archives, 10 (11).

[5] Chadwick, V. (1989) Equal Opportunities in the Teaching Profession - The Myth and the Reality, in De Lyon, H. \& 
Widdowson - Migniulo, F. (Eds) Women teachers. Issues \& experiences (Milton Keynes, Open University Press, 97 109).

[6] De Lyon, H. \& Widdowson - Migniulo, F. (Eds) (1989) Women teachers. Issues \& experiences (Milton Keynes, Open University Press).

[7] Frosi L.L. (2010). The gender in the school and in the discourse of the teachers. Athens: Topos.

[8] Glass, T. (2000) Where Are All the Women Superintendents? June 2000 in The School Administrator Web Edition AASA'S latest study on the profession suggests seven reasons why female numbers still lag in top district posts.

[9] Grant, R. (1986) A career in teaching: a survey of teachers' perceptions with particular reference to the careers of women teachers, paper presented at the British Educational Research Association Annual Conference, Bristol.

[10] Guide of studies at In-Service Teacher Training Unit of Patras (2002), Patras.

[11] Iordanidis, G. (2002) The role of Head of Regional Education Offices (Thessaloniki, Kyriakidis Publish, in Greek).

[12] Inner London Education Authority (1984) Women's Careers in Teaching: A Survey of Teachers' Views, (London, ILEA Research and Statistics).

[13] Inner London Education Authority (1987) Women's Careers in Secondary and Primary Teaching: The Birmingham Study, by R. Martini, (London, ILEA Research and Statistics).

[14] Kant, L. (1985) A question of judgement, in J. Whyte et al., Girl Friendly Schooling, (London, Methuen).

[15] Kergoat, D. (2008). Social relations and the gendered distribution of labour. In M. Markani (Ed.), Women, gender, societies. Athens: Metaichmio.

[16] Morgan, A. (1989) Equal Opportunities, Promotional Prospects and Special Education - Trends for Women in One Welsh County, in De Lyon, H. \& Widdowson - Migniulo F (Eds) Women teachers. Issues \& experiences (Milton Keynes, Open University Press, 58-66).

[17] Nickel H.M. (2010). The change in work and the professional integration of women. In N. Vaiou \& M. Stratigaki (Eds), Gender and research. Athens: Metaichmio.

[18] O' Connor, V. (2001) Women and men in senior management - a "different needs" hypothesis, Women in Management Review, 16 (8), 400-404.

[19] Patiniotis, N. (1996) The Greek scientists from abroad in Records of the 5th International Conference of Greek Pedagogiki Association. The education in United Europe (Eds Kosmopoulos, A. Ifanti, A. Petroulakis, N. Athens, 2nd edition Ellinika Grammata Publications, 222-244, in Greek).

[20] Robertson, H. (1995) Teacher Development and Gender Equity in Hargreaves, A. \& Fullan, M. Understanding Teacher Development, [translated into Greek] (Athens, Patakis Publishing, 77-105).

[21] Saiti, A. (2000) Women teachers and management of education in Greece", Ta ekpedeftika, 57-58, Athens, 150-163, (in Greek).

[22] Vasilou-Papageorgiou, V. (1995) Education and gender: The dimension of gender in teaching staff of primary education, in Kazamias, A. \& Kassotakis, M. (Eds) (1995) Greek education: prospects of reconstitution and modernization (Athens, Seirios Publishing, 495-514, in Greek).

[23] Wood, G. \& Lindorff, M. (2001) Sex differences in explanations for career progress, Women in Management Review, $16(4), 152-162$. 